\title{
Paradox of the Consumer: Case Study on MSMEs in Pacitan Regency (MSME Case Study in Lorok Wiroyo Village, Ngadirojo District, Pacitan Regency, East Java)
}

\author{
R. Adjeng Mariana Febrianti ${ }^{1 *}$, Sriwardani ${ }^{2}$, Siska Juniar ${ }^{3}$, Rany Asih Apsari ${ }^{4}$ \\ Widyatama University, Bandung Indonesia \\ 1*adjeng.mariana@widyatama.ac.id, ${ }^{2}$ sriwardani@unla.ac.id, ${ }^{3}$ siska.juniar@widyatama.ac.id, \\ ${ }^{4}$ rany.apsari@widyatama.ac.id
}

Article History: Received:11 January 2021; Accepted: 27 February 2021; Published online: 5 April 2021

\begin{abstract}
This study aims to analyze the influence of price fairness and employee satisfaction on customer satisfaction with service delivery as an intervening variable in Batik MSMEs in Pacitan. This study used path analysis with of SPSS 23 software. The sample in this study as many as 68 people incidentally. The conclusion in this study is that variable price fairness and employee satisfaction affect customer satisfaction with service delivery as intervening variables. This research was conducted to find out aspects in measuring customer satisfaction which is closely related to the performance of MSMEs especially in the city of Pacitan in the batik sector, and also emphasizes the importance in providing prices and quality of services provided by employees to obtain customer satisfaction to ultimately generate loyalty.
\end{abstract}

Keywords: Price fairness, quality of service, customer satisfaction, delivery service

\section{Introduction}

In general, micro, small and medium enterprises (MSMEs) have good competitiveness in the economy (Octavian \& Indrawijaya, 2020). MSMEs can survive and play a role in carrying out their functions both in the production of goods and services when the economy is faced with uncertain business problems and conditions (Wuen \& Ibrahim, 2020). This is quite reasonable considering that the MSME sector has prospects to be developed, it also has different characteristics with companies in general. In addition to having advantages over other business scales, MSMEs also have an important role in the national economy. SMEs have a strong influence on the economy in all countries (Mital et al., 2019). SMEs contribute to national economic stability in all developing countries (Myslimi \& Kacani, 2016). The competitive environment among customers and potential buyers shows that a variety of factors play a role in creating awareness, satisfaction, and loyalty. In contemporary environments, the only constant thing is change (Febrianti, 2020).

Therefore, businesses must develop different strategies in order to survive in the long term (Brettel \& Malte, 2015). One of the best strategies is to satisfy customers who ensure long-term business growth. Nowadays organizations are well aware of the benefits that lie with retaining customers and trying to figure out the reasons that can influence purchasing decisions (Brozzi et al., 2018). Satisfied customers are the main concern of every organization, especially MSMEs. Therefore, the organization is very attentive to the factors that influence the purchase decision. In the context of SMEs, especially batik in the city of Pacitan, East Java Province, the role of price and quality of services provided by workers is needed to improve customer satisfaction. Looking at its history, Pacitan batik is inseparable from the influence of Mataram batik style that is in Surakarta Solo. Geometric and nongoemetric patterns are found in batik motifs in Pacitan. The location of MSMEs in Pacitan regency consisting of mountainous areas, hills, and coastal areas is also an attraction for tourists who want to visit the city.

The main objective of this research study is to find out the key variables that have a strong influence on customer satisfaction in the MSME sector especially in the city of Pacitan. This study has considered two main important factors, namely price fairness and employee satisfaction (quality of service provided) to know how it affects customer satisfaction. Factors that affect customer satisfaction as well as service delivery as intervening variables. The problem formulations in this study are:

1. Does price fairness affect customer satisfaction?

2. Does the Quality of Service affect customer satisfaction?

3. Does the fairness of the price and quality of service affect the delivery service?

4. Does the fairness of the price and quality of service affect customer satisfaction through service delivery? 


\section{Theoretical Studies}

\subsection{Price fairness}

According to Kotler (2017), the price is a certain amount of money charged for a product or service or a certain amount of value or product and service. For consumers, price is a decisive factor in the decision to buy a product or not. Consumers decide to buy if the perceived benefits are greater or equal to those that have been incurred to get them. Pricing is the most difficult thing among the elements in the marketing mix. Price is the only element in the various elements of the marketing mix that can provide benefits for organization. Wolter and Bock (2019) define the price as the amount of money or goods needed to acquire the company's goods or services. Pricing made by a company or business must pay attention to the purpose of pricing itself (Wolter, 2019). This is important, because goals are the basis or guidelines for companies in pricing. The purpose of pricing is 1) obtaining maximum profit, 2) getting a certain market, 3) earning profit from the market segment (market skimming), 4) achieving the maximum sales revenue level, 5) achieving the targeted profit, 6) promoting the product. According to Kotler (2017), the price dimension consists of, affordability, conformity to quality, conformity to benefits, and conformity to ability. Wolter (2019) shows price fairness refers to consumer assessment of whether the seller's price is reasonable, acceptable or justifiable (Certo \& Withers, 2016). Fairness of price is a very important issue that leads to satisfaction. Reasonable pricing helps develop customer satisfaction and loyalty.

\subsection{Employee satisfaction}

The employee satisfaction component represents a learning and growth perspective because it provides infrastructure for achieving the other three perspectives and to generate long-term growth and improvement for the organization. Simply put, the definition of job satisfaction is the satisfaction that a worker feels individually when doing his or her job. Job satisfaction of a worker, especially in the context of MSMEs can be seen when he serves consumers According to Febrianti (2020), Li and Bruch (2017), the emotional influence of workers is the main theory to study the relationship between employee satisfaction in serving their customers (Suchanek \& Richter, 2015). The emotional state is built on the idea that emotions are expressed in social interactions and shows the results of a more enjoyable customer experience from the influence of transfer, in which satisfied employees express positive emotions, both verbally and non-verbally, that can have an influence on the customer. That is, employees' actions reflect their emotional state, and customers capture these displayed emotions.

\subsection{Customer satisfaction}

Customer satisfaction is defined as an evaluation of the perceived discrepancy between previous expectations and the actual performance of the product. Customer satisfaction is basically how customers evaluate the products and services provided by the organization (Febriyanti, 2020). According to customer satisfaction is the customer's reaction to the state of satisfaction, and the customer's assessment of the level of satisfaction. Customer satisfaction is very important in today's business world because according to Vakuelenko (2019), the ability of product and service providers to create a high level of satisfaction is essential for product differentiation and developing strong relationships with customers. According to Dholakia and Zhao (2010), the existence of customer satisfaction can provide benefits, including building corporate and customer relationships to be harmonious, providing a good basis for repurchasing, and encouraging the creation of loyalty. According to Firher (2016) and Febriyanti (2020), the dimension of customer satisfaction consists of, price, quality of service provided, product quality, emotional factors, and pride in using the product.

\subsection{Service delivery}

Kocek and Leonard (2018) mentioned that human involvement in providing services to consumers is inseparable from the support of facilities. Cooperation between organizations and delivery service providers is urgently needed, because organizational and consumer contacts must be supported by means that are factors that can represent the organization and can directly influence the formation of the organizational image. According to Lovelock (2018), every business both services and non-services is seen as a system consisting of a service operating system and a service delivery system. In the delivery system, this relates to something delivered to the customer, covering the elements of the system in the operation of the service and other things presented to the 
consumer. Reliable delivery has been referred to as the source of customer value. Factors such as on-time delivery (Lovelock, 2018), price, and total delivery time (Buntaine \& Daniels, 2018) have been accepted as an anthedent for customer satisfaction and loyalty

\subsection{Frame of mind}

The frame of thought in this study can be seen in Figure 1:

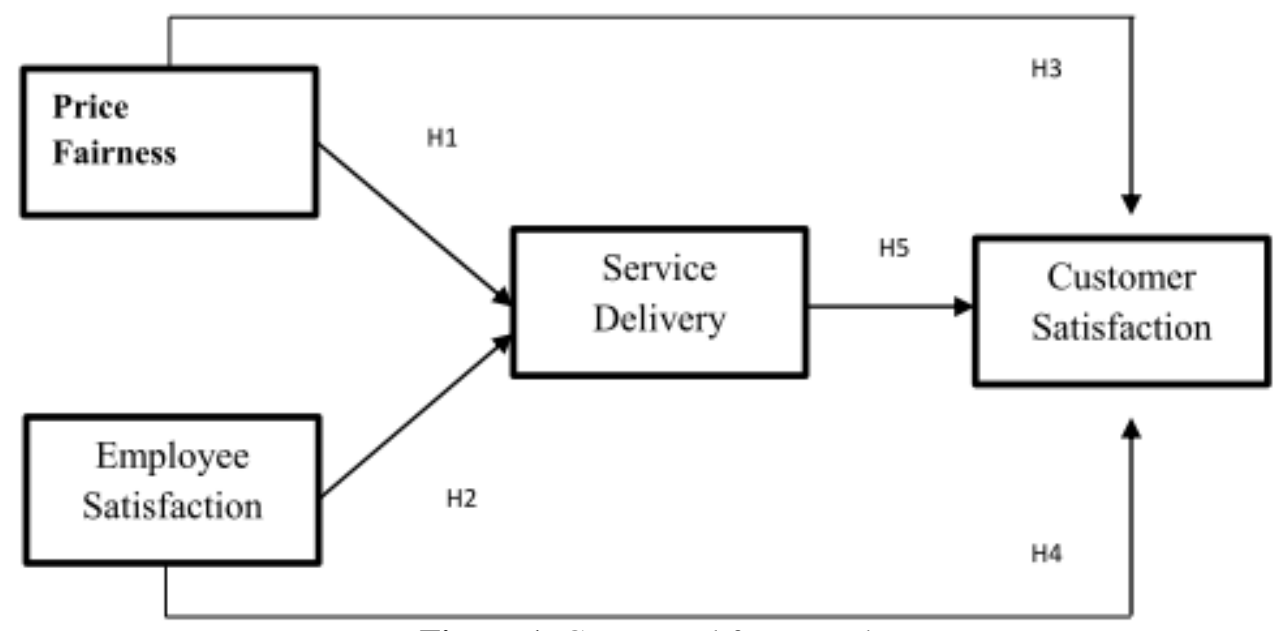

Figure 1. Conceptual framework

\subsection{Effect of price fairness on service delivery}

Because consumers tend to pay great attention to prices when making a purchase, but if the delivery is negative it will have an impact on overall customer satisfaction and future consumer relationships with retailers will be less good. Considering this, according to Wolter (2019), price fairness without the accompanying quality of service in delivery affects customer satisfaction. The delivery experience makes the customer dissatisfied (for example, the wrong item or item is taken to a place far from the pickup location). As a result, customers can turn to other retailers in an effort to avoid future service failures.

H1. Fairness of price affects the quality of delivery services

\subsection{Effect of employee satisfaction on service delivery}

In the delivery system, it relates to something that is conveyed to the customer, covering the elements of the system in the operation of the service and other things presented to the consumer. Reliable delivery has been referred to as the source of customer value. Job satisfaction of a worker, however, affects customer satisfaction in terms of delivery. A worker must serve the consumer in full from preparing the product to the delivery stage. According to $\mathrm{Li}$ and Bruch (2017), the emotional influence of workers is the main theory for studying the relationship between employee satisfaction in the service of its consumers (Huang \& Li, 2015).

H2. Employee satisfaction affects service delivery

\subsection{The effect of price fairness on customer satisfaction}

Price is the only element in the various elements of the marketing mix that can provide benefits for organization. The fairness of the price given and the way it is determined has a huge impact on satisfaction. According to the products offered to customers will always be sensitive to the price offered. This is why, some consumers show the substantive role of price fairness and service quality with customer satisfaction. Fairness of price is a very important issue that leads to satisfaction. Reasonable pricing helps develop customer satisfaction and loyalty.

H3. Price fairness affects consumer satisfaction

\section{9. effect of employee satisfaction on customer satisfaction}

According to Berdur and Drummond (2020), employee satisfaction can be seen from the emotional factors when serving customers. According to Kamar and Novitasari (2020), an employee's emotional appearance 
affects customers when they want to make a purchase. Usually the situation that occurs in the transaction process, consumers will choose several variants of products in the store. However, when the waiter gives a good expression, the consumer will immediately leave it. Asbari and Wijayanti (2020) shows that employee satisfaction can affect customer satisfaction. This is supported by the phenomenon of trends or facts on the field indicates that customer satisfaction may change when employees or waiters show less pleasant expressions. Studies show that the services provided are often involved in transaction situations.

H4. Employee satisfaction affects customer satisfaction

\subsection{0. the effect of price fairness and employee satisfaction affects customer satisfaction through service delivery}

Wolter (2019) provides evidence that customer satisfaction levels may vary between the payment stage and after delivery. This indicates that delivery has an impact on overall customer satisfaction. From a customer experience perspective, delivery delays have an impact on customers' perception of the shopping experience (Govin et al., 2018). According to Spike (2020) reveals the relationship between customers' perception of the shopping experience and their experience after package delivery greatly affects customer satisfaction. It can be assumed that if the delivery is negative it will have an impact on overall customer satisfaction.

H5. Fairness of price and employee satisfaction affect customer satisfaction through service delivery.

\section{Research Methodology}

This research uses quantitative analysis approach by adopting multiple regression analysis techniques. The sample in this study was 68 respondents. The sampling technique in this study is non Probability sampling with incidental sampling. According to Sekaran (2016), incidental sampling is a technique of determining samples based on coincidence at the time that is used as a sample if there is a match as a sample. The data sources and data methods used in this research are observations, interviews, and questionnaires or questionnaires. While secondary and primary data using Likert scale.

\section{Results and Discussion}

\subsection{Characteristics of respondents}

Table 1. Characteristics of respondents

\begin{tabular}{cccc}
\hline No. & Age & Amount & Percentage \\
\hline 1 & $25-30$ years old & 7 & $10,3 \%$ \\
\hline 2 & $31-35$ years old & 19 & $27,9 \%$ \\
\hline 3 & $36-40$ years old & 10 & $14,7 \%$ \\
\hline 4 & $41-45$ years old & 11 & $30,9 \%$ \\
\hline 5 & $>45$ years old & 21 & $16,2 \%$ \\
\hline \multicolumn{4}{c}{68} \\
\hline No. & Education & Amount & Percentage \\
\hline 1 & SD & 4 & $5,9 \%$ \\
\hline 2 & SMP & 2 & $2,9 \%$ \\
\hline 3 & High School / Vocational High School & 28 & $41,2 \%$ \\
\hline 4 & Diploma & 10 & $14,7 \%$ \\
\hline 5 & S1/S2 & 24 & $35,3 \%$ \\
\hline \multicolumn{4}{c}{68} \\
\hline No. & Status & Amount & Percentage \\
\hline 1 & Unmarried & 5 & $5,9 \%$ \\
\hline 2 & Married & 63 & $92,6 \%$ \\
\hline \multicolumn{4}{c}{}
\end{tabular}

Source: Data processed 2020

Price fairness variables provided by batik retailers can have an impact on consumers. Table 1 shows that based on age characteristics $30 \%$ of batik users are at the age of 41-45 years. Based on the level of education is in the 1st and 2nd degree. Based on characteristics of marital status, 92.1\%. Validity test results on price fairness variables ( 5 items), employee satisfaction ( 5 items) customer satisfaction ( 5 items) and service delivery (5 items) have significant value $>0.235$ or in other words valid. The reliability test is as follows: 
Table 2. Reliability test

\begin{tabular}{cccc}
\hline Variable & Cronbach Alpha & Critical Value & Description \\
\hline Price Fairness & 0,922 & 0,60 & Reliable \\
Employee Satisfaction & 0,938 & 0,60 & Reliable \\
Customer Satisfaction & 0,938 & 0,60 & Reliable \\
Service Delivery & 0,952 & 0,60 & Reliable \\
\hline Source: Data processed 2020. & \multicolumn{4}{l}{}
\end{tabular}

The responses regarding the research variables are as follows:

Table 3. Respondent responses

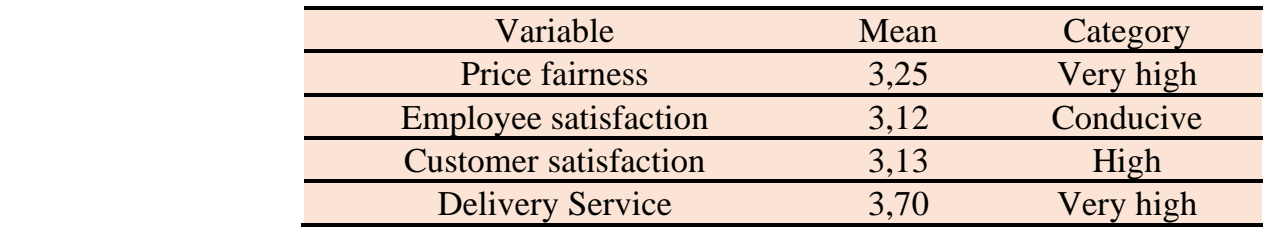

Source: Data processed 2020

Variable fairness price has a value of 3.25 (very high) this indicates that the consumer is very attentive to the price as a consideration in making a purchase when visiting the store where he will buy. Employee satisfaction variable has a value of 3.12 (conducive) this indicates that the satisfaction of employee in serving consumers has an up and down flow. It is also influenced by the style of communication between the seller and the buyer that occurs in the transaction situation. Variable customer satisfaction is at a value of 3.13 (high) this indicates that the condition of the store and service or in the transaction environment provided can affect customer satisfaction in making a purchase. The service delivery variable is at a value of 3.70 (Very high) this indicates that customer satisfaction is not only measured when transactions occur, but also in delivery or delivery also has an impact on customer satisfaction.

Table 4. Hypnotic test

No. Hypothesis

fairness of price affects service delivery $\quad$ Proven

2 employee satisfaction affects service delivery $\quad$ Proven

3 price fairness affects customer satisfaction $\quad$ Proven

4 employee satisfaction affects customer satisfaction $\quad$ Proven

5 price fairness and customer satisfaction affect customer satisfaction through service delivery Proven

Source: Data processed 2020

\subsection{The effect of price against service delivery}

The result of regression analysis shows that price fairness variable has a significant influence on service delivery with probability value t- calculate $(0.002)<$ Level of Significant $(0.05)$. This result is supported by Wolter and Bock (2019) which shows that price fairness can affect the quality of service, especially delivery, then Vakulenko (2019) mentions that the low price given by retail has an influence on delivery services with high categories.

\subsection{Effect of employee satisfaction on service delivery}

The result of regression analysis shows that the $\mathrm{F}$-calculate $(0.000)<$ Level of Significant $(0.05)$. These results support Oktavia (2020) which shows that the influence of employee satisfaction on emotional variables and communication affects service delivery. Mital (2019) states that communication that is not effectively intertwined can affect product delivery for example (errors in delivery and delivery time).

\subsection{Effect of price fairness on customer satisfaction}


The results of the regression analysis showed that price fairness variables have an influence on customer satisfaction with the value probability $t_{\text {calculate }}(0.001)<$ Level of Significant $(0.05)$. These results are supported by Fisher (2016) which states that products offered to customers will always be sensitive to the price offered, thus affecting customer satisfaction.

\subsection{The effect of employee satisfaction on customer satisfaction}

The results of regression analysis showed that employee satisfaction variables have an influence on customer satisfaction with the probability value t. calculate $(0.039)<$ Level of Significant $(0.05)$. The results of this study are supported by Certo and Withers (2016) which shows that employee satisfaction can be seen from the emotional factors when serving so that it has an impact on customer satisfaction.

\subsection{Effect of price fairness and employee satisfaction on customer satisfaction with service delivery as intervening}

The results of mediation test prove service delivery to be variable intervening between price fairness and employee satisfaction to customer satisfaction. These results can be seen in the results of multiple regression tests as follows:

Table 5. The results of multiple regressions of price fairness and employee satisfaction with service delivery Coefficient $^{\mathrm{a}}$

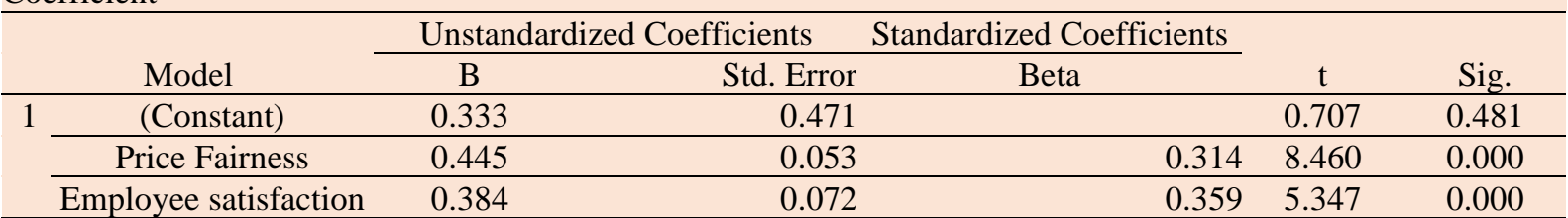

a. Dependent Variable: Service delivery

Source: Primary data processed, 2020

Table 6. Multiple regression results for fairness of price, employee satisfaction, and service delivery on customer satisfaction

Coefficient ${ }^{\mathrm{a}}$

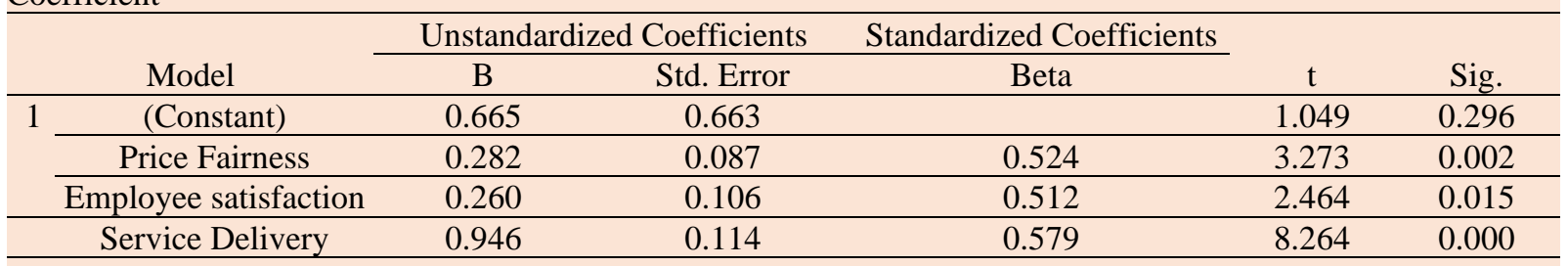

a. Dependent Variable: Service delivery

Source: Primary data processed, 2020

Table 7. F test for fairness of price, employee satisfaction and service delivery on customer satisfaction ANOVA ${ }^{b}$

\begin{tabular}{cccrrrr}
\hline Model & & Sum of Squares & df & Mean Square & F & Sig. \\
\hline 1 & Regression & 1749.893 & 3 & 589.998 & 250.274 & $.000 \mathrm{a}$ \\
\hline & Residual & 320.507 & 136 & 2.357 & & \\
\hline & Total & 2.070 .400 & 139 & & & \\
\cline { 2 - 7 }
\end{tabular}

Source: Primary data processed, 2020

Figure 1 where the direct influence of price fairness variable gives a value of 0.314 to service delivery. The employee satisfaction variable to service delivery obtained a value of 0.359 . The effect of price fairness variable on customer satisfaction was obtained by 0.524 and the effect of employee satisfaction on customer satisfaction was obtained 0.512 . While, the influence of price fairness and employee satisfaction through service delivery obtained a value of 0.579 . 


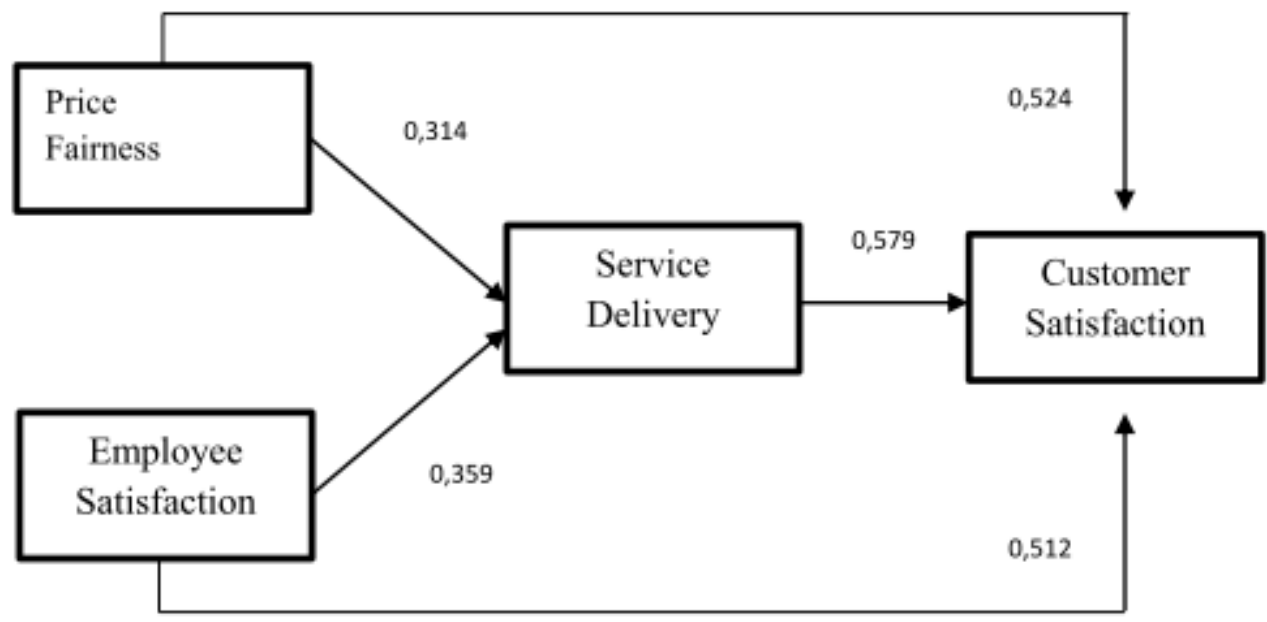

Figure 2. Path analysis test result

\section{Conclusion}

\subsection{Conclusion}

From the results of this research, it can be concluded as follows:

Variable price fairness and consumer satisfaction have an influence on service delivery. With this result, it can be concluded that the price and quality of service provided to customers can improve customer satisfaction. Conversely, if the variable price and employee satisfaction is less than maximum then it can have a negative impact on customer satisfaction.

Variable price deliberateness and consumer satisfaction affect customer satisfaction through service delivery. This shows that in addition to price and service factors, the delivery provided by the MSME organization in Pacitan to customers can have a direct influence on customer satisfaction.

If the customer is satisfied with the price and the right service and delivery, it will give rise to loyalty.

\subsection{Suggestions}

The results of this study conclude that price reasonableness and employee satisfaction in serving have an effect on customer satisfaction with service delivery as an intervening. This research was conducted at UMKM Batik in the city of Pacitan with a sample of 68 respondents with variable prices, employee satisfaction, customer satisfaction and service delivery. In further research, there may be other variables that are not discussed in this study, such as shop feasibility, product variants, etc. which can increase customer satisfaction.

\section{References}

1. Aker, J.C., Collier, P., \& Vicente, P.C. (2017). Is Information Power? Using Mobile Phones and Free Newspapers During an Election in Mozambique. Review of Economics and Statistics, 99(2), 185-200.

2. Berdud, M., Drummond, M., \& Towse, A. (2020). Establishing a reasonable price for an orphan drug. Cost Effectiveness and Resource Allocation, 18(1), 1-18.

3. Brunetti, A., and Weder, B. (2003). A Free Press Is Bad News for Corruption. Journal of Public Economics, 87(7), 1801-1824.

4. Brettel, Malter, Christoph Chomik, and Tessa Christina Flatten. (2015). How Organizational Culture Influences Innovativeness, Proactiveness, And Risk-Taking: Fostering Entrepreneurial Orientation in SMEs. Journal of Small Business Management, 53(4), 868-885.

5. Brozzi, R., R. D. Amico, G. Pasetti, C. Marcher, M. Riedl, and D. Matt. (2018). Design of selfassessment tools to measure industry 4.0 readiness. A methodological approach to craftsmanship SMEs. In Ifip International Conference on Product Lifecycle Management. Paolo Chiaber, Abdelaziz Bouras, Frédéric Noël, and José Ríos (Eds.), 566-578. Cham: Springer.

6. Certo, S. T., Withers, M.C., and Semadeni, M. (2016). A Tale of Two Effects: Using Longitudinal Data to Compare Within- And Between Firm Effects. Strategic Management Journal, 38(7), 1536 - 1556. 
7. Dholakia, R. R., And M. Zhao. (2010). Effects of Online Store Attributes On Customer Satisfaction and Repurchase Intentions. International Journal of Retail \& Distribution Management, 38(7), 482 496.

8. Fisher, M. L., Gallino, S., \& Xu, J. J. (2019). The value of rapid delivery in omnichannel retailing. Journal of Marketing Research, 56(5), 732-748.

9. Febrianti, M, A, Uman, S, Yuni, A, and Khalila. (2020). Improving SME Performance Through, Network, and Technology (Study on SME Songket Weaviing Favrics Bali Province). Solid State Technology, 63(4).

10. Govind, R., Chatterjee, R., \& Mittal, V. (2018). Segmentation of spatially dependent geographical units: Model and application. Management Science, 64(4), 1941-1956.

11. Huang, M., Li, P., Meschke, F, and Guthrie, J. P. (2015). Family Firms, Employee Satisfaction, and Corporate Performance. Journal of Corporate Finance, 35, 108 - 127.

12. Kotler, K and Amstrong. (2017). Marketing: An Introduction. Pearson Ltd.

13. Koscek, K and Leonard. (2018). Can Information Improve Rural Governance and Service Delivery? International Food Policy Research Institute.

14. Lovelock, K. (2018). Service Marketing. Pearson Ltd.

15. Li, J., Burch, T.C., \& Lee, T. W. (2017). Intra-Individual Variability in Job Complexity Over Time: Examining the Effect of Job Complexity Trajectory on Employee Job Strain. Journal of Organizational Behavior, 38(5), $671-691$.

16. Mital, S, Khan, A, Purohit, Menon, K, And Romero. (2019). A Smart Manufacturing Adoption Framework for SME's. International Journal of Production Research, 58(5), 1555-1573.

17. Octavian, A, And Indrawijaya, S. (2020). Impact on E-Commerce Adoption on Entrepreneurial Orientation and Market Orientation in Business Performance of SMEs. Asian Economic and Financial Review, 10(5), 516.

18. Now, U. (2016). Methodology Research, Pearson Ltd.

19. Suchanek, P and Richter. (2017). Customer Satisfaction, Product Quality and Performance of Companies. Review of Economic Perspectives, Vol. 14, Issue 4.

20. Vakulenko, Y, Shams, P, Daniel, and Klas. (2019). Online Retail Experience and Customer Satisfaction: The Mediating Role of Last Mile Delivery. The International Review of Retail, Distribution and Consumer Research, 29(3), 306-320.

21. Wuen, H, Ibrahim, F, And Ringim. (2020). The Impact of Human Resource Management Practices on SMEs Performance: An Exploratory Study in Brunei Darussalam. International Journal of Asian Business and Information Management, 11(2), 68-87.

22. Wolter, S and Bock, D. (2019). Employee Satisfaction Trajectories and Their Effect on Customer Satisfaction and Repatronage Intentions. Journal of the Academy of Marketing Science, 47(5), 815836. 